\title{
Environmental Histories and Emerging Fisheries Management of the Upper Zambezi River Floodplains
}

\author{
James G. Abbott ${ }^{a t}$ and Lisa M. Campbell ${ }^{\mathrm{b}}$ \\ aDepartment of Geography, Nipissing University, 100 College Drive, Box 5002, North Bay, ON, Canada P1B 8L7 \\ (Research carried out while author was a Ph.D. candidate at the Nicholas School of Environment, Duke University)

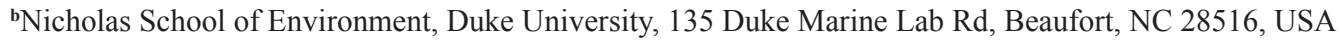

${ }^{\#}$ Corresponding author. E-mail: jabbott@nipissingu.ca

\begin{abstract}
In response to a widespread decline in fisheries, scientists and policy makers have constructed models outlining the biological and social drivers that cause changes in fishing intensity and methods identified with overfishing. The models also address the consequences of overfishing, namely changes in biomass, trophic structure and ecosystem resilience, as well as increased poverty and vulnerability of the fishers, particularly in the developing world. While these models have emerged from marine and coastal fisheries, they have also been used to identify overfishing in floodplain fisheries and to guide management recommendations. In this article, we critique the assumptions of a global overfishing narrative describing the serial depletion of fish species, increased fishing effort and fisher dependence, which are considered valid by various stakeholders in the floodplain fisheries of the Upper Zambezi River. We find that researchers highlight how the inherent variability of the floodplain environment defies the simple diagnoses of overfishing, based on changes in effort and methods or livelihood. However, the views of policy makers and local users on the 'problem of overfishing' are that the fish biomass is declining and intensive fishing methods are to blame, which largely resonate with the narrative. We consider how differing emphasis on parts of the narrative by stakeholders has implications for management, and what such differences tell us about the malleability of narratives.
\end{abstract}

Keywords: small-scale fisheries, environmental narratives, floodplain fisheries, sub-Saharan Africa

DOI: $10.4103 / 0972-4923.58641$

\section{INTRODUCTION}

In 2002, a project to distribute subsidized mosquito nets in the far northeast region of Namibia faced a problem. It had become apparent to the non-governmental organisation (NGO) responsible that some inhabitants were using the mosquito nets to catch fish. As a response, T-shirts were widely distributed, bearing the message that mosquito nets should be used for malaria protection, not fishing (Figure 1). However, objections to the use of mosquito nets for fishing did not arise only because they were being used for something other than their intended purpose, or the risk to people eating fish contaminated by pesticide-treated nets (e.g. New Era 2008). ${ }^{1}$ Mosquito net fishing is also viewed by policy makers in Namibia and elsewhere as a particularly destructive fishing method, contributing to the general decline in the area's fish stocks, and the Namibian government and traditional

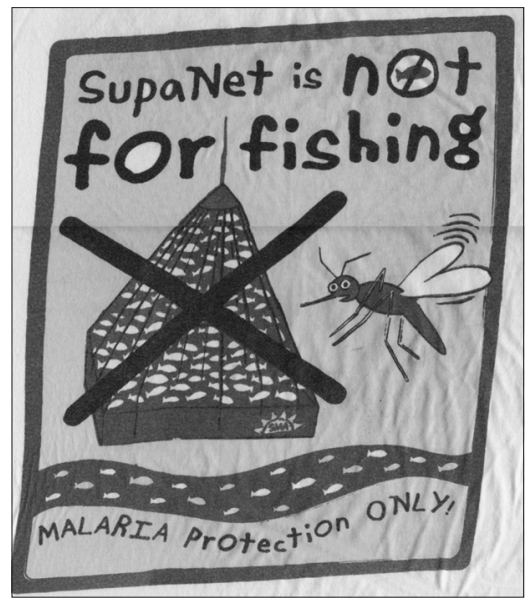

Figure 1: Detail of T-shirt distributed as part of the awareness campaign against using subsidised mosquito nets for fishing in North-east Namibia, 2002

Copyright: (C) Abbott and Campbell 2009. This is an open access article distributed under the terms of the Creative Commons Attribution License, which permits unrestricted use and distribution of the article, provided the original work is cited. 


\section{4 / Abbott and Campbell}

authorities in the area make provisions for restricting such intensive methods.

Each sweep of a mosquito net in the water does yield a catch consisting of very small fish (Figure 2), seemingly reinforcing concerns about overfishing and justifying the prohibition of this method. These beliefs and justifications stem from a broader overfishing narrative, where the use of highly intensive fishing methods such as small-mesh nets is depicted as both a cause and consequence of interrelated biological and socioeconomic crises. However, the actual effects of this fishing method on fish stocks have not been examined systematically in the floodplain environments of the Upper Zambezi River or elsewhere. This lack of data, combined with the complex social and biological environments of floodplains, means that the limited information available must often be interpreted in the context of how tropical fisheries behave elsewhere.

Policies on fisheries based on assumptions or generalizations about causative linkages between fishers, their behaviour and fish stocks risk being ineffective if the assumptions turn out to be false. In this case, restricting intensive fishing with mosquito nets in the Upper Zambezi River risks depriving some of the most vulnerable groups of an important source of protein. This is because the majority of mosquito net fishing is done by women and children, who typically occupy marginal positions in the region. Furthermore, while their livelihoods are most vulnerable to restrictions on mosquito net fishing, women and children have little influence in shaping management decisions.

In this article we describe a global narrative of overfishing and the direct and indirect causal factors implicated in it. We then consider the extent to which this narrative resonates among a wide range of actors in the Upper Zambezi River floodplains in Southern Africa. We argue that within this study area, the majority of claims about intensive fishing resonate strongly with the global narrative among almost all actors. However, different groups emphasize different direct and indirect causal factors and indicators to make conclusions about changes in fish stocks and why these changes occur. Although the overfishing narrative generally supports more management intervention, this differential emphasis on particular causal factors supports

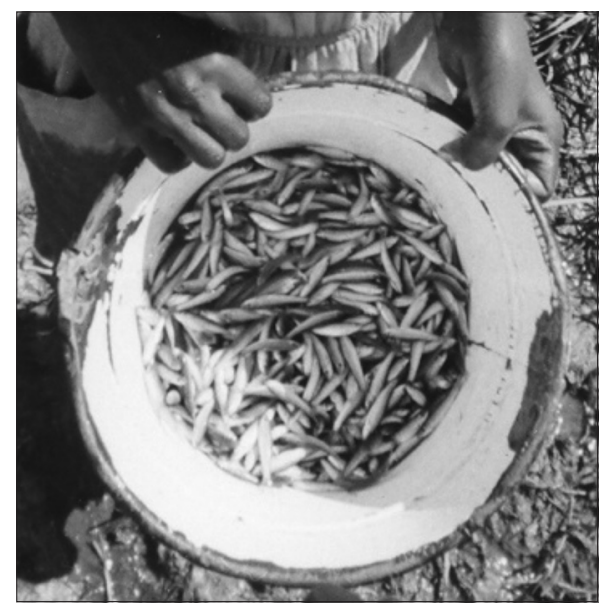

Figure 2: Sample of a catch from a mosquito net used for fishing in the Zambezi River, 2002 different forms of intervention, and interventions promoted by particular stakeholders reflect their interests. Our concern here is not to evaluate whether or not the narrative is 'correct', but rather to explore how the narrative 'works' for a diverse set of stakeholders with seemingly different interests, and with what consequences. Given the ambiguity of Namibia's new fisheries legislation (introduced in 2003 and described in detail a little later in the article), such consequences are not strictly of academic interest; as Namibia looks to change its fishing practices, the ability of any one group to capture the attention of policy makers may be associated with real outcomes, for example, a ban on intensive fishing methods, like the use of mosquito nets.

Environmental narratives often depend on anecdotal evidence, assumptions about the causes, consequences, meanings of environmental change and results of research undertaken in one place or time and then applied to another. (Eg., Leach \& Mearns 1996; Keeley \& Scoones 2000). For example, Keeley \& Scoones describe how the current legitimacy of soil degradation narratives in Ethiopia still largely stem from two seminal studies published in the mid 1980s. Scientists have often been implicated in the formation and uptake of environmental narratives, as the authority of science often allows research results to be readily transferred from one context to another (Forsyth 2003). However, the role of science is one of the features of our case study that departs from other critical analyses of policy narratives; scientists and the primary research they produce within our case study site is not used to legitimise an overfishing narrative. As we will show, most primary research reviewed in our study is optimistic about the state of the floodplain fishery, and several researchers question the assumption that intensive methods targeting small fish are unsustainable. In spite of this locally produced and contextualised science, many policy documents we review cite intensive fishing, specifically the use of mosquito nets, as both a cause and a consequence of the fisheries crisis, and as a justification for management intervention.

In examining environmental narratives associated with floodplain fisheries, we add to a growing body of literature examining environmental processes and their associated impacts on livelihoods in Africa. Terrestrial environments and livelihoods, such as protected areas, pastoralism and agriculture, have largely dominated critiques of how African environments and livelihoods are perceived and managed. This focus is reasonable, since it is on land that the most prevalent 'environmental orthodoxies' such as poaching, deforestation, and erosion (Forsyth 2003) have unfolded (Eg., Leach \& Mearns 1996; Keely \& Scoones 2000; Hulme \& Murphree 2001; Bassett \& Crummey 2003). However, we believe attention to fisheries is also warranted, given the importance of fisheries in the livelihoods of a large part of Africa (FAO 1996).

Besides the biological and social complexity of floodplain fisheries (Welcomme 1979; Winemiller 2004), we see three reasons for considering how environmental narratives persist and shape resource management policy in floodplain fisheries. First, as already noted, artisanal fishing is an important livelihood in large parts of Africa (FAO 1996) and floodplain 
fisheries are largely artisanal, providing important sources of protein and income (Eg., Adams 1993; Thomas \& Danjaji 1997). Second, boundaries established during Africa's colonial era had frequently used rivers as reference points and this means that many African inland fisheries are transboundary resources (Sadoff et al. 2002; Nakayama 2003), further complicating management (Abbott et al. 2007a). Third, recent projections of climate change in sub-Saharan Africa suggest that large areas of the region will undergo considerable drying (Thomas \& Twyman 2005). Projected patterns of precipitation and flooding, if accurate, will lead to dramatic changes in southern Africa's floodplain environments and fisheries, in addition to the other resource-based activities that make up most inhabitants' livelihood strategies (Purvis 2002a).

Our article is structured as follows: First, we discuss the concept of narratives, in particular how different types of knowledge and understanding become embedded in an explanatory narrative. In particular, we draw attention to the narrative's three interdependent and mutually-reinforcing assumptions: (i) Exploitation leads to a serial reduction of fish biomass, species diversity and trophic complexity; (ii) Reduced yields cause a correspondent increase in fishing effort and use of intensive fishing methods; (iii) Fishers become increasingly poor and dependent on fishing.

Second, we consider how well the assumptions inherent in this narrative fit with the current scientific understanding about the ecology and livelihood strategies of African floodplain fisheries. In particular, the non-equilibrium nature of floodplain ecosystems and the fundamental influence of annual and decadal flood cycles on the productivity of the fishery and the livelihoods of inhabitants require careful consideration. We draw particular attention to how periods of resource scarcity and intensive use challenge the largely linear trajectories assigned to fisheries and fishing livelihoods by the overfishing narrative. We then use a case study to consider how the overfishing narrative is constructed by different actors (researchers, policy makers, recreational fishers, floodplain inhabitants) in the Upper Zambezi River floodplains, to what extent the causal factors and indicators inherent in this narrative are apparent at the local level, and consider how the different actors might benefit from supporting an overfishing narrative when Namibia's new inland fisheries legislation is applied. We conclude the article with a discussion on the relevance of our work for the narrative concept more generally.

\section{Environmental Narratives}

Scientific and political discourses about environmental degradation and unsustainable resource use often take the form of what has been termed a narrative (Roe 1991). A narrative is often useful and arguably necessary, as it allows decision-makers to define and explain problems in the face of complex and uncertain situations (Roe 1991). In constructing a 'problem', types of information and their sources are both implicitly and explicitly given different levels of importance, relevance and logical order, thus streamlining the types of data that go into understanding a situation. Furthermore, a narrative is a 'story' of a problem that identifies the actors and prescribes a solution that is intuitively logical, given the evidence (Leach \& Mearns 1996; Forsyth 2003; Smith \& Link 2005 also discuss how analogies are used to understand why fisheries fail). The simplified patterns of cause and effect, combined with the intuitive logic of solutions, means that policy makers, scientists and the public at large often adopt environmental narratives, including those that identify a crisis and its causes, uncritically.

The role of science in informing environmental narratives has been of particular interest, as science is often the basis on which problems are described (Keeley \& Scoones 2000; Campbell 2002, 2007). Like narratives themselves, science seeks and creates 'generalised' knowledge that can be replicated and applied across various contexts. As a result, science and scientists have sometimes failed to recognise contrary local evidence that better explains environmental change or resource use (Leach \& Mearns 1996; Forsythe 2003; Robbins 2004). Reasoning arising from generalised models means that the information may be ignored or misinterpreted in the face of assumed truths about a resource and its users. This deductive flaw especially characterises environmental narratives that: (a) Rely on information based on limited spatial or temporal contexts (i.e., environmental 'snapshots'), and (b) Assume that the environments are largely stable unless disturbed by exploitation or that environmental change occurs largely through unidirectional causative linkages (Eg., intensive slash and burn agriculture ultimately causes transition to grasslands, Leach \& Mearns 1996). Similarly, resource management policies arising from environmental narratives, especially those that ignore environmental variability, can actually make livelihoods less adaptive, more vulnerable and less sustainable (Johnson \& Anderson 1988).

\section{The Global Overfishing Narrative}

Over the past decade, a crisis narrative in fisheries has emerged and been widely adopted, (Eg., Millennium Ecosystem Assessment 2005) with some analysts predicting the impending collapse of almost all commercially valuable marine fish stocks over the next 20 years (Worm et al. 2006; but see Beddington et al. 2007). Declines in trophic structure, biomass and catch per unit effort are cited as proof of overfishing, or 'fishing down the food chain' (Pauly et al. 2005). Catches may stabilize or even increase (Mullon et al. 2005), but as the number of fishers and/or effort increases, fishers are obliged to increase their efforts further, often through more intensive methods of extraction. In doing so, the fishery becomes progressively less diverse and fish become smaller and less abundant.

Within this narrative, the apparent cause of overfishing is largely linked to institutional failure in several forms (Alverson 2002). Unsustainable levels of fishing occur when governments either do not regulate at all (such as in open-access fisheries), or structure access in such a way that fishers 'race to fish' for a collective quota within a limited time period (Hilborn et al. 2005; Beddington et al. 2007). Overfishing may also occur when governments provide subsidies promoting more intensive and 
economically inefficient fishing effort, while at the same time reducing the cost (Parma et al. 2006). If the problem defined by the overfishing narrative is high and/or damaging fishing effort, the intuitive logic would be to restrict the effort or stop it altogether. This can be accomplished through decommissioning fleets, removing subsidies, promoting high value fishing for sport or tourist consumption, establishing marine protected areas, and introducing individual (or community-based) transferable quotas (see Campbell et al. 2009).

\section{Small-scale Fisheries and the Global Overfishing Narrative}

The models and empirical data that support the global overfishing narrative are derived largely from commercial temperate fisheries in developed countries. However, smallscale fisheries (SSFs), particularly in tropical regions of the developing world, are characterised by a similar crisis narrative of overfishing in both marine (Pauly et al. 1989; Pauly 1997; Sadovy 2005; Akapul 2008; Basurto 2008; Cinner et al. 2008) and freshwater settings (FAO 2003; Allan et al. 2005). The assumptions made about how the fisheries respond to exploitation are similar to the general narrative in a biological context (i.e., increase in effort combined with a serial decline in trophic complexity, Crowder et al. 2008. p. 271). However, SSF narratives are distinct in that they stress population growth, poverty, erosion of traditions, modernisation and incorporation into market economies as factors driving overfishing.

Small-scale fishers play an important role in overfishing narratives by causing changes in the fishery as well as responding to the broader socioeconomic forces. While low levels of fishing, using traditional methods under customary arrangements, may have been sustainable, the overfishing narrative depicts this sustainability as being overwhelmed by a combination of increasing human population, poverty, modernisation and the entrance of fishers from outside the area. Because fisheries are common pool resources, fishing is increasingly relied upon to meet growing food and income demands by existing and new subsistence and commercial fishers. As overall fishing increases, fishing methods become more intensive, and this leads to a decline in the catch per unit effort as well as a change in the size and species of fish caught (McClanahan et al. 2008). The synergistic interaction of these socioeconomic and biological factors leads to an accelerating degradation of the fishery. Traditional management regimes for these SSFs either become overwhelmed by high levels of fishing activity or are eroded by influxes of outsiders who are unfamiliar with or do not recognise customary arrangements (Scudder \& Connelly 1985; Pauly 1997; McGoodwin 2001; Haller \& Merten 2008).

Guided by this narrative, the use of intensive and apparently unsustainable fishing methods, such as mosquito nets, can be interpreted in a number of different ways. Most importantly, fishers using highly intensive methods, especially those that mainly catch small fish, can be seen as evidence that overfishing is already taking place and placing the fishery at risk. Such forms of fishing, following the narrative's logic, would most likely occur once the fishery has already been depleted of larger fish, hence changing the composition of the catch and accelerating the move towards more intensive methods. Fishers using such methods may be understood as either unaware of the consequences of their actions or unwilling to change despite evidence of declining fish stocks. Similarly, the open-access nature of fisheries, and recent increases in the number of fishers in an area could be blamed for causing a runaway 'Tragedy of the Commons' (Hardin 1968) or again, for making fisheries an 'occupation of last resort' (Allan et al. 2005; p. 1049).

Alternatively, a more contextualised interpretation might see such behaviour as a part of a progressive and reinforcing cycle of ecological degradation and socioeconomic marginalisation. Marginalised individuals fish intensively to meet gaps in subsistence and income; as a result, the fishery begins to show declining returns in the number and size of fish, compelling marginalised groups to fish even more intensively, what Béné, (2003) refers to as a 'circular and auto-reinforcing paradigm' (p. 967). Regardless of the causal interpretation, the overfishing narrative logically calls for measures to limit fishing intensity and methods, although the means and institutions most appropriate for implementing these measures remain open to debate (Eg., the relative desirability of market mechanisms like Individual Transferable Quotas versus community-based or co-managment regimes, Parma et al. 2006, p. 417-420).

Recent critiques argue against the linearity in the overfishing narrative. For example Allison \& Ellis (2001), Béné (2003), Andrew et al. (2007) and Cinner et al. (2008) have called for understanding of SSFs as part of a broader set of livelihood activities. These authors argue that the intensity of fishing and the methods used by fishers are not simply a product of the environmental characteristics of their surroundings or a rational response to economic demands (see also Abernethy et al. 2007). Decisions to fish are made in the context of the relative costs and benefits of other livelihood options. Social and cultural institutions, such as gender, age, income and ethnicity also shape the access to fishing and the methods used; complicating explanations for the observed fishing patterns (see also Salas \& Gaertner 2004). This complexity is also argued by Scudder \& Connelly (1985), who, while categorising how a river fishery changes from subsistence to commercial through four progressive 'stages', point out that different participants may be characteristic of different stages even within the same fishery. In spite of these perspectives, concern for the sustainability of SSFs remains largely couched in the language of the dominant narrative (Akpalu 2008).

\section{Floodplain Fisheries and the Global Overfishing Narrative}

Inland floodplain fisheries are the subset of SSFs that are of interest in our paper. To a large degree, management concepts and objectives in inland fisheries are still largely based on marine fisheries (Berkes et al. 2001; Coates et al. 2003), and inland fisheries in Africa have received far less attention than their coastal or marine counterparts (Béné 2005). However, the distinct environmental and socioeconomic characteristics of floodplain fisheries mean that intensive fishing practices 
and high reliance on fishing may take on different meanings than they have in marine or coastal fisheries, small-scale or otherwise. Of primary importance are the roles of seasonal and inter-annual variations in flooding, which have profound effects on floodplain fisheries and livelihoods. The existing research indicates that (a) floodplain fisheries are inherently multispecies and variations in fish biomass are strongly affected by flooding volume and duration (Welcomme 1979; Junk et al. 1989; Arthington et al. 2003; de Graaf 2003); (b) participants in floodplain fisheries use a wide variety of methods at different places and times (Welcomme 1979); (c) floodplain livelihoods often include periods of intense fishing activity in response to seasonal abundance of fish or scarcity of other resources (Evans-Pritchard 1940; Hickling 1961; Adams 1993; Sarch 1996; Thomas \& Adams 1997; Sarch \& Birkett 2000; Shorr 2000; Evans \& Mohieldeen, 2002), as well as longer term livelihood shifts in response to changes in fish abundance (Thomas \& Adams 1997; Sarch \& Birkett 2000, Allison \& Ellis 2001; Jul-Larsen et al. 2003); (d) floodplain fisheries appear to be robust to even high levels of exploitation (Welcomme 1979; Mosepele et al. 2002; Jul-Larsen et al. 2003; Fox \& Sneddon 2005), although exploitation can lead to changes in their trophic structure, over time (Laë 1997; Welcomme 1999).

This combination of natural variability, multiple fishing methods, varying intensity and catches, often composed of several different species, makes identifying management priorities and assessing policy effects challenging (Muncy 1978; Scudder \& Connelly 1985; Hoggarth et al. 1999; Adger \& Lutrell 2000; Jul-Larsen et al. 2003). For example, Muncy (1978) noted that the challenges of identifying 'underutilization' or 'overfishing' in African floodplain fisheries was due to the fact that the two concepts had largely been developed in the context of fisheries models assuming constant physical and biological parameters. The variability of both floodplain environments and livelihoods challenge these assumptions of constant recruitment and growth rates, as well as how fishers react to change (Muncy 1978; Jul-Larsen et al. 2003).

Despite the recognised complexity of floodplain fisheries and livelihoods, direct and indirect indicators are still used persuasively by policy makers to argue that overfishing is taking place, and to identify the specific causes and advocate specific solutions; that is, the overfishing narrative holds sway. This is true in the Upper Zambezi River floodplain fisheries, where concerns about fishing, as expressed by a variety of stakeholders, rely on the same assumptions about what constitutes overfishing, its causes and effects. This is perhaps not surprising, as high levels of complexity make it more likely that a narrative will be both adopted and its assumptions will be faulty (Roe 1991). In this region, the consequences of adopting a flawed (or incomplete) narrative will be greatest for a highly vulnerable segment of society who depend on their livelihood strategies remaining as flexible as possible (Allison \& Ellis 2001), and who are likely to have little voice in any policy change.

In exploring the case of floodplain fisheries in the Upper Zambezi River, we have three main objectives: (1) To show how the global overfishing narrative resonates at the local level with a variety of stakeholders, in spite of the existing understanding of floodplains, as reviewed earlier, and of the specific scientific research in our case study area; (2) to illustrate how narratives remain malleable, in that different stakeholders with seemingly contrary objectives can adopt the same narrative because they can emphasize and downplay particular assumptions in the overfishing narrative to suit their needs, and (3) to consider the potential management implications of this differing emphasis by different stakeholders. To a certain extent, the article may be read as a critique of the overfishing narrative, but our primary intention is to critique its untested application to this particular place, and the potential consequences thereof. At the same time, we recognise that overfishing can and does occur in fisheries in floodplain environments (examples include fisheries described by Jackson 2000, Gordon 2005 and Haller \& Merten 2008).

\section{CASE STUDY: THE UPPER ZAMBEZI RIVER FLOODPLAINS}

Our case study focused on the section of the Zambezi River and the approximately 304,600 ha of floodplains (Turpie et al. 1999) framed by the confluence of the Zambezi River to the north and the Chobe River to the south. A majority of the research described in this article was conducted in the Namibian portion of the floodplains, known as the Caprivi Region, although research was also carried out on the Zambian side of the Zambezi River.

The study region was relatively remote, but due to its proximity to several political borders and its physical geography, it had experienced periods of dramatic change. Each new political and institutional arrangement was accompanied by increasingly restrictive policies concerning transboundary access to natural resources, including fisheries (Fisch 1999; Abbott et al. 2007a). Demographically, settlement in this area was largely rural, consisting of households and villages scattered throughout the floodplain or along semi-permanent roads. Using aerial photos, Mendelsohn \& Roberts (1997), concluded that the number of households in one area of the floodplains had quadrupled between 1943 and 1996, although this growth rate was lower than other parts of the Caprivi. The portion of the Zambezi River within our study site and upstream had little evidence of human modification. Aside from a few bridges, there were no physical barriers, and there was no irrigation beyond a few small farm operations. There were also no industrial activities or large urban areas in this region.

The floodplains experience a bimodal pattern of precipitation and flooding each year, typical of tropical river systems. Recent analyses of decadal trends indicate that the Zambezi River has decreased its annual flow volume since the early 1980s (Mazvimavi \& Wolski 2006). Within this trend there is considerable intra-annual variation in the Zambezi River's annual volume. For example, Herbert (2002), cites memoirs of the record flood of 1957, and the fear among administrators and inhabitants alike that villages would be drowned, whereas, 30 years earlier the whole area had been abandoned by inhabitants for lack of water. Similarly, Lake Liambezi, fed 
by a tributary of the Zambezi, was a highly productive fishery until it dried out completely in 1985 (Mendelsohn \& Roberts 1997). Recent years have demonstrated equally dramatic contrasts between consecutive years, such as the record low floods in 2002 and the record high floods in 2004 that refilled Lake Liambezi (The Namibian 2004).

The fisheries ecology of the region is characteristic of tropical floodplains (Welcomme 1979; Junk et al. 1989), with abundance and species distribution influenced by seasonal flooding (Næsje et al. 2002). Inter-annual trends in flood volume and timing may also affect the floodplain's productivity, similar to patterns described elsewhere (Lindholm et al. 2007), although this is not known at present. The rising waters spill the banks of the main channel and spread across the floodplain, leading to an explosion of primary production in the shallow flooded areas. The majority of fish breeding cycles coincide with this period, where adults migrate onto the floodplains to lay eggs as well as feed. As the flood slackens, adult and juvenile fish alike either return to the main channel with the retreating waters, or become trapped in the seasonal water bodies. The distinct temporal and spatial trends in fish species abundance have a particular significance in the role of fishing in livelihood strategies and institutional arrangements, as described a little later in the article.

\section{Livelihoods in the Upper Zambezi River Floodplains}

Most inhabitants depend on the area's natural resources and their livelihoods often combine fishing, farming, livestock and off-farm activities (Purvis 2002a). Fishing is a common characteristic of the past and present livelihoods of the area (Zeller 1998; Tvedten 2002) and besides formal employment and pensions; it is one of the few livelihoods providing both a reliable source of income and a daily source of protein (Ashley \& LaFranchi 1997; Purvis 2002a). The fishery is artisanal in nature with distinct gender roles. Men fish with gill nets, barriers, and drag nets in dugout canoes, while women and children are largely restricted to using mosquito nets, traps, hooks, and baskets from the shore (Purvis 2002a). Marketing of fish is done almost exclusively by women (Purvis 2002b; Abbott et al. 2007b). There is also a small but important tourism industry based on the area's wildlife, in particular catering to recreational fishing; however, few local inhabitants are employed in this sector (and none surveyed in any of our research).

While we focus on fishing narratives in Namibia in this article, it is important to note that the Zambezi River is a shared resource. A 2002 survey of villages along both the Namibian and Zambian sides of the Zambezi River revealed important trends in population growth and distribution (Abbott et al. 2007a) that inform overfishing narratives. Each settlement had fishers, and most riverside settlements were permanent (i.e., not vacated during the rainy season). The number of settlements had increased over time, with the majority having been established in the last 10 years. Moreover, most settlements and over 95 percent of the estimated total population of riverside inhabitants were on the Zambian side of the river (Abbott et al. 2007a). This larger regional context of increased fishing activities by Zambians becomes important in the narratives of some stakeholder groups, particularly those of the Namibian fishers.

The relative importance of fishing has changed since Namibia's independence in 1990, when the Caprivi's rural economy was largely based on agriculture (Næraa et al. 1993). The causes for this shift may be a series of poor rainy seasons - the eastern Caprivi region in particular had abnormally poor rains in 2001/2002 compared to the previous five-year average (FEWS 2002). Other reasons include the cessation of agricultural subsidies, both directly through the end of government provision of free ploughing, and indirectly through the removal of subsidies that made cheap seed and fertilizer available from the adjacent countries (Abbott 2005). In addition, during 2002, the prices for staple foodstuffs (including maize) increased in Namibia by nearly 25 percent, with a 13.3 percent increase in the consumer price index overall (FEWS, 2002).

\section{Fisheries Tenure and Management}

There has been little fisheries management in the area by the national government until recently, and traditional management has in the past focused mostly on the tenure of seasonal water bodies. The seasonable variability of the floodplain landscape is the primary factor shaping local institutional arrangements for fishing. During the low flood season, water is confined to either the main channel or isolated bodies of water (mulapos). These mulapos are valued not only for concentrating fish, but also for their relatively humid and nutrient rich soils that are exposed as waters recede. Most mulapos are 'owned' by specific individuals or families and permission must be asked to fish in them (Tvedten et al. 1994; Abbott 2001; Purvis 2002a). Fishers assert their tenure over certain areas during the onset of flooding by placing weirs (sinyandi) across channels in order to catch fish as they migrate to their breeding areas in the floodplain and as they return to the main channel with the ebbing floodwaters. When the floodplain is inundated, the fishery becomes largely 'open access'. At least three factors can contribute to this seasonal shift in tenure: Distinct bodies of water associated with the tenure can no longer be distinguished, the dispersal of fish across the floodplains makes them more difficult to catch, and many households begin ploughing upland fields in anticipation of the rainy season, leading to a labour shortage for fishing (Abbott 2005).

Prior to Namibian independence in 1990, the South Africanbacked administration ruled by devolving management of certain natural resources, including fisheries, to tribal authorities in each homeland established under apartheid. After independence, uncertainty about the status of traditional authorities (Hinz 2003) meant that Namibia's inland fisheries management remained undefined in the absence of a new policy (Abbott 2001). Policy reform was also slow to emerge. During the early 1990s, responsibility for inland fisheries passed through three ministries, before research and management duties finally coalesced within the Namibian Ministry of Fisheries and Marine Resources (Abbott 2001). In 2003, the new inland fisheries legislation came into force. The legislation closely resembled the 2000 Marine Fisheries Act, 
which was designed largely for offshore commercial fisheries. As such, the 2003 Inland Fisheries Resources Act had only a general acknowledgement of the role of non-state institutions, and a very malleable set of regulatory measures such as closed seasons and mesh-size limits (Abbott 2005). The malleability lay in the fact that the application of any specific measure was left to the discretion of the state, based on perceived threats to the sustainability of the fishery and through consultation with local councils and traditional authorities (Government of Namibia 2003). Because implementation of the act was responsive to local conditions and institutions, various stakeholders had both room and incentives to ensure that their particular interpretation of local conditions dominated.

Changes in the Upper Zambezi River floodplain fisheries and livelihoods, as well as the environment in general, are therefore an outcome of a complex set of environmental, political and economic factors, operating at different scales over time. Inter-annual trends in flooding, combined with changes in livelihoods and institutional and economic environments, all leave space for contrasting theories about if, how and why fish stocks and fishing activity has changed, and to what degree this signifies overfishing. Actors perceive change differently and may accord contrasting levels of significance to the causes and effects they identify as most important in influencing change and, more importantly, their construction of an overfishing narrative. The potential differences are important because the ambiguity in the new legislation provides considerable potential for different actors to assert their legitimacy as stakeholders, and to promote specific management measures. In the following sections, we examine perceptions among different social actors of the causes and effects of changing fishing strategies and fish stocks, and consider how these perceptions support particular types of interventions.

\section{MATERIALS AND METHODS}

Examining the basis and evolution of policy discourse requires drawing on a wide range of published and unpublished sources (Keeley \& Scoones 2000). In this article, these include results of our own research and sources uncovered through an extensive literature search. Regarding our own research, field work in the region was undertaken from April 2002 to December 2003 as part of J. Abbott's doctoral research, and involved a series of primary data collection efforts. For the purpose of this article, results from this research are summarized rather than explored in detail, and readers are directed to other publications for further data resulting from specific research activities (Table 1). Regarding the literature search, we sought research articles, policy documents and consultancy reports written by a broad range of actors, which address the science and policy for fishing in the Upper Zambezi River. We searched major scientific and media databases (ISI Web of Knowledge, Access World News), and collected relevant documents while in the region. Although the views of some stakeholders, namely researchers, are captured in published scientific articles (Van der Waal \& Skelton, 1984, 1990), the majority of sources are
Table 1

Sources used to examine perceptions among different social actors of the causes and effects of changing fishing strategies and fish stocks of the Upper Zambezi River

\begin{tabular}{|c|c|}
\hline Source and reference & Coverage \\
\hline $\begin{array}{l}\text { Fishing village } \\
\text { survey (Abbott } \\
\text { 2005; Abbott et al. } \\
\text { 2007a) }\end{array}$ & $\begin{array}{l}\text { All settlements in Namibia and Zambia along } \\
\text { a portion of the Zambezi River shared between } \\
\text { the two countries. } \\
\text { In total } 73 \text { settlements were recorded and } \\
541 \text { structured interviews with fishers were } \\
\text { completed; September-November } 2002\end{array}$ \\
\hline $\begin{array}{l}\text { Intensive Namibian } \\
\text { household surveys } \\
\text { (Abbott unpublished } \\
\text { data) }\end{array}$ & $\begin{array}{l}\text { Random stratified survey of households } \\
\text { in the Namibian floodplain in Kalimbeza } \\
(n=14) \text {, Impalila }(n=10) \text {, Musanga }(n=9) \\
\text { and Nakabolelwa }(n=10) \text { villages; March } \\
\text { 2002-November } 2002\end{array}$ \\
\hline $\begin{array}{l}\text { Extensive Namibian } \\
\text { household surveys } \\
\text { (Abbott et al., in } \\
\text { review) }\end{array}$ & $\begin{array}{l}\text { Random stratified survey of } 429 \text { fishing and } \\
\text { non-fishing households of census districts } \\
\text { in the Namibian constituency where the } \\
\text { floodplains are located (Kabbe); July and } \\
\text { September } 2002\end{array}$ \\
\hline $\begin{array}{l}\text { Key informant } \\
\text { interviews (Abbott } \\
\text { unpublished data) }\end{array}$ & $\begin{array}{l}12 \text { traditional authorities and other older } \\
\text { male residents in Zambia and Namibia; May } \\
\text { 2002-November } 2002\end{array}$ \\
\hline $\begin{array}{l}\text { Market vendor } \\
\text { surveys and } \\
\text { interviews (Abbott } \\
\text { et al. } 2007 \mathrm{~b})\end{array}$ & $\begin{array}{l}\text { Surveys: } 591 \text { market vendor surveys completed } \\
\text { over a 1-year period, with } 300+\text { different } \\
\text { vendors working in the central market of } \\
\text { Katima Mulilo, the Caprivi Region's capital } \\
\text { in Namibia; April 2002-March } 200344 \text { in- } \\
\text { depth interviews; April 2002-December 2002; } \\
\text { December } 2003\end{array}$ \\
\hline $\begin{array}{l}\text { Participant } \\
\text { observation at } \\
\text { community meetings }\end{array}$ & $\begin{array}{l}4 \text { Meetings attended in Impalila, Kalimbeza, } \\
\text { Ihaha and Nakabolelwa administrative wards; } \\
\text { July-August } 2002\end{array}$ \\
\hline Document analysis & $\begin{array}{l}\text { Historical documents, policy documents, } \\
\text { legislation, news articles, scientific articles on } \\
\text { fishery and floodplain livelihoods }\end{array}$ \\
\hline
\end{tabular}

'grey' literature, documents produced by government, NGOs and consultants, often with limited circulation. Discourse emerging from government and consultancy documents is often particularly important in driving narratives. For example, Keeley \& Scoones (2000), constructed their entire discourse analysis either from policy documents (both government \& NGO), consultant reports, or interviews with government officials and consultants. The high proportion of grey literature also highlights the relatively small amount of primary research that has been conducted in the area, and the even smaller amount that has been published in peer-reviewed sources. We also use articles published in the press, where stakeholders express their views in letters to the editor and editorials, and where stories related to fisheries appear. It is often in these types of sources, rather than the academic literature, that policy narratives are formed, diffused and repeated.

Stakeholders in fishing narratives include scientists, policy makers (both governmental and non-governmental), recreational fishers and floodplain inhabitants. The Namibian government, scientists and NGOs active in the country often collaborate closely on environmental and developmental projects. The political and social circumstances that have led 


\section{0 / Abbott and Campbell}

to the co-evolution of shared priorities and stakeholders in each group (Murphy \& Abbott, 2006) make separating them as distinct social actors impractical. We choose instead to draw a distinction between views based largely on the primary sources (i.e., research conducted by the authors themselves), and views based largely on secondary sources (i.e., literature reviews of work done elsewhere) or anecdotal data. While individuals identifying with either source may come from the government, academy or NGOs, we refer to those drawing on primary sources as researchers and those drawing on secondary sources as policymakers.

Recreational fishers and the related industry form a small but important stakeholder group in fisheries narratives, as their claims to fish can be construed as competing with claims of small scale fishers. Given the increasing importance of tourism in the region (Namibia Tourism Board, 2009), their claims may correspondingly gain increased weight among policy makers. Among floodplain inhabitants, we consider the views of fishers and non-fishers, and of traditional authorities; it is the views of local inhabitants that are derived mainly from our primary research. While most of the research was conducted with residents on the Namibian side of the river, views of Zambian fishers were captured in a frame survey (Table 1) and are included later in the article, where relevant.

\section{RESULTS}

\section{Views about Fisheries and Fishing}

The factors that researchers, policymakers, recreational fishers and floodplain inhabitants deem as having important effects on fisheries can be categorised as either environmental (Eg., natural cycles, changes in habitat), technical (Eg., changes in fishing methods) or demographic (Eg., population growth or migration). These categories are not mutually exclusive and often occur together in explanations. In the following sections, we describe the factors that are emphasized by each group and how this emphasis influences their suggested approach to fisheries management in the area.

\section{Views of Researchers}

Scientific literature about the socioeconomic and biological dimensions of the area's fisheries is limited, reflecting in part its geographical and institutional isolation, as well as the relatively limited attention given to African inland fisheries in general (Béné 2005). However, documents covering a time span from 1966 to 2003, describe qualitative and quantitative data collection, exploring links between fish populations and human activity in the area. The first of these is a synthesis of fisheries research conducted between 1966 and 1969 on the Zambian portion of the floodplains (Bell-Cross 1974). Bell-Cross (1974) concluded that limited data made an accurate assessment of the ecological impact of fishing impossible, but also asserted that the apparent species diversity and abundance suggested that the fishery was under-exploited. The report cited several potential drivers of declining fish stocks, including direct causes such as lower-than-average floods, and indirect causes such as changes in floodplain ecology. Bell-Cross (1974) particularly cautioned against prohibiting intensive fishing methods, such as poison, if ' [T] he general acceptance of its adverse affects is based on sentiment and not on any sound biological basis' (p. 305). The report recommended increased research capacity in the Upper Zambezi floodplains in order to better understand the fishery's ecology before implementing concrete measures.

Both Bell-Cross (1974) and Tweddle (2003) specifically evaluated the ecological impact of highly extractive fishing methods, such as, the use of baskets, noting that these methods could initially appear very destructive to fish stocks. However, both authors point out that this type of fishing typically takes place in ephemeral pools whose populations of minnows would die regardless, as pools dried up. Bell-Cross (1974) also emphasized that intensive fishing methods targeting small fish were important to subsistence diets during the dry season.

Van der Waal and Skelton (1984) conducted a survey of the fishery on the Namibian side of the Zambezi River, noting that fishers relied on large mesh gill nets and hence were highly selective of the larger species, tending to overlook adults of the smaller species. A greater catch, they argued, could be achieved by making smaller mesh sizes available without risking overexploitation of juveniles. Further survey data collected by Van der Waal (1990), led him to conclude that the ratio of nets per fisher, and hence individual fishing effort, had actually declined between 1975 and 1980, due to gear supply problems and extensive net damage by crocodiles and hippos. Catches also declined in these years, a trend that Van der Waal (1990) speculated was due to the aforementioned decline in nets per fisherman or a series of low floods.

More recently, the high species diversity and catch per unit effort yielded by fish surveys conducted between 1997 and 2000, on the Namibian side of the river, indicated that the fisheries in the Namibian portion of the floodplain were relatively undisturbed by human impacts (Hay et al. 2002). Koekemoer (2003) analysed the same data to a greater extent, concluding that catch effort and species diversity varied largely throughout the floodplain and did not directly indicate overfishing.

These findings, suggesting that the area's fishery had a relatively low level of human disturbance, reflected conclusions made by Næsje et al. (2001), who analysed effort, fisher distribution and catches from a local angling competition held in 2000. The catch/effort estimates arising from the competition led Næsje et al. (2001) to state that the overall recreational fishery in that part of the Zambezi River was 'excellent' (p. 24) and that angling would not significantly affect recruitment to the fish stock. Koekemoer (2003) also examined the species composition of the fish caught in extremely small mesh nets, concluding that the majority of fish caught were adult minnows, rather than juveniles of larger fish species. However, Koekemoer (2003) did express concern about the 'callous use of dragnets with fine mesh by commercial fishermen' (p. 13), saying it could have a deleterious effect on the fishery. 
Tvedten et al. (1994) focused on the socioeconomic aspects of the region's freshwater fisheries (Tvedten et al. 1994; see also Tvedten 2002). The authors used focus group interviews, fisher surveys as well as reviews of background literature to make specific recommendations about the Caprivi fisheries. Tvedten et al. (1994) stressed that the high level of biological variability in the region's fishery, combined with its widespread yet varied importance to the region's livelihoods made management difficult. The lead author also suggested elsewhere that traditional authorities tolerated the use of baskets and mosquito nets to catch fish because these methods were mainly used in relatively brief (albeit intensive) periods by the most marginal (and usually female-headed) households to supplement diet (Tvedten 2002; p. 434). Any management, Tvedten et al. (1994) argued, should be formulated and implemented at the most local scale possible. Moreover, management decisions to restrict certain potentially damaging fishing methods, such as small mesh nets, must be considered in socioeconomic as well as biological contexts.

In summary, researchers have recognised how environmental variability affected fish stocks and livelihoods. They tended to view the potential effect of fishing in the context of where and when fishing takes place, and under what conditions, rather than absolute levels of extraction.

Researchers who mentioned the use of intensive fishing methods often drew attention to the socioeconomic context of the activity, in terms of what segment of the community practised it and whether the catch was used mainly for subsistence or income generation. The studies described earlier in the article do not deny that overfishing may take place under certain circumstances of low flooding or ecosystem alteration, but are cautiously optimistic about the status of local fisheries. We find no primary research that argues for a concrete and predominant link between current fishing methods and adverse effects on the area's fisheries. The main management recommendation of scientists is to caution against arbitrarily assuming deleterious effects to fish stocks in the absence of proof.

\section{Views of Policy Makers}

Recent resource management activity in the region contrasts the previous laissez-faire approach of the Namibian government and the limited presence of NGOs prior to independence. In 1996, the Namibian Government released the White Article on the Responsible Management of the Inland Fisheries of Namibia, (Government of Namibia 1996) based largely on the recommendations made by Tvedten et al. (1994). Above all, the White Article emphasized the need to favour subsistence over commercial use of fisheries. In addition, the White Article recommended favouring passive over active fishing methods, and traditional over modern fishing methods, two recommendations that have particular significance towards fishing methods such as mosquito nets.

With the exception of the legal framework for fisheries management, the Namibian Government and several NGOs now regard fisheries in the Upper Zambezi River, as well as other Namibian rivers as being at risk. Policy documents discuss several factors as contributing to this risk, including ecological changes, such as a series of low flood years (Mendelsohn \& Roberts 1997; Barnard 1998; Chenje 2000) and indirect human effects (such as overgrazing of floodplain habitats by livestock (Mendelsohn \& Roberts 1997; Abbott 2001), a growth in population and/or fishers (Government of Namibia 1996; Byers 1997; Timberlake 1998; Chenje 2000).

Intensive fishing methods are identified by several policy makers as either an indicator that overfishing is taking place, or as a risk to the sustainability of the fishery. Table 2 provides evidence of both concerns for overfishing and beliefs about the source of the problem, as stated in the existing policy documents. Factors leading to this shift to intensive methods include the introduction of modern fishing gear (Schlettwein et al. 1991; Byers 1997; Barnard 1998; Abbott 2001; Chenje 2000; Okeyo 2000; Government of Namibia 2003), commercialisation (Abbott 2001), and waning traditional management (Byers 1997; Okeyo 2000). Declines in overall fish biomass, catch and the size of fish species are also used by policy makers as evidence of overfishing (Timberlake 1998; Barnard 1998; Chenje 2000). We also draw attention to the fact that out of the eight documents we reviewed, four explicitly mention mosquito net use as direct proof of a crisis in the area's fisheries (Barnard 1998; Chenje 2000; Okeyo 2000; Government of Namibia 2003).

Close examination of the cited policy documents suggests that claims about overfishing and its causes made by policy makers are either asserted without citation or through inference, (Schlettwein et al. 1994; Timberlake 1998; Okeyo 2000; Government of Namibia 2003), rely on other secondary sources (Byers 1997; Chenje 2000; Abbott 2001) or have partial interpretation of primary documents (Barnard 1998). For example, several sources cite Van der Waal (1990) in claiming that declining catches over time indicate overfishing is taking place. However, Van der Waal suggests that this decline has occurred due to a decline in the number of nets, rather than changes in the fish biomass itself. In addition, small-mesh fishing is assumed to have a significant effect on fish stocks, and hence the risk that mosquito net fishing poses is presented as self-evident. Two documents (Chenje 2000 and Okeyo 2000) do mention that women primarily use small mesh nets. However, they do not place its use in the context of how gender shapes the use and access of the area's fisheries.

In constructing a narrative that identifies risks to the area's fisheries and their causes, it is not surprising that policy makers also recommend solutions (Table 2). These solutions are either general (i.e., research and increased management of fisheries) or specific (i.e., ban destructive fishing practices, strengthen traditional management measures, promote local scale management and increase the role of state institutions in fisheries management). Three documents either directly or implicitly identify women, or the intensive fishing methods they predominantly use, as areas of management focus.

\section{Views of Recreational Fishers}

Recreational fishers usually come from outside of the region and stay at one of the many small lodges along the Zambezi 
Table 2

Selected excerpts from policy documents that discuss threats to the Upper Zambezi River floodplain fishery

\begin{tabular}{|c|c|c|}
\hline Definition of problem & Proposed solutions & Citation \\
\hline $\begin{array}{l}\text { 'Local inhabitants have turned to intensive fishing.using seine nets } \\
\text { stretched to the full length of the river and up to four nets deep. This } \\
\text { unsustainable level of fishing may have drastic consequences on the } \\
\text { recovery of fish populations once the floods return again.' (p. 72) }\end{array}$ & $\begin{array}{l}\text { None mentioned specific to fisheries, although the } \\
\text { authors caution against alteration of floodplain } \\
\text { hydrology by roads, or disruption of ecosystem } \\
\text { functions by grass fires and overgrazing }\end{array}$ & $\begin{array}{l}\text { Schlettwein } \\
\text { et al. (1991) }\end{array}$ \\
\hline $\begin{array}{l}\text { 'Overfishing in Caprivi has resulted from a combination of } \\
\text { environmental changes and increased fishing pressure from modern } \\
\text { gear.' (p. 26) (repeating verbatim from Tvedten et al., 1994) }\end{array}$ & $\begin{array}{l}\text { Strengthen management overall, and in particular } \\
\text { traditional management }\end{array}$ & Byers (1997) \\
\hline $\begin{array}{l}\text { 'All studies so far report a reduction in catches as fisheries have moved } \\
\text { from baskets to nylon nets.' (p. 143) } \\
\text { 'Overexploitation of fish populations is of great concern where small- } \\
\text { mesh nets, even mosquito nets, and year-round pressure simply remove } \\
\text { all size classes.' (p. 141) }\end{array}$ & $\begin{array}{l}\text { 'Clearly, tighter controls are required to make } \\
\text { these fisheries sustainable.' (p. 143) }\end{array}$ & $\begin{array}{l}\text { Barnard } \\
(1998)\end{array}$ \\
\hline $\begin{array}{l}\text { 'Owing to the high human populations and aspirations in Caprivi, there } \\
\text { is reportedly much overfishing resulting in changes in both the aquatic } \\
\text { ecology and species composition' (p. 93). }\end{array}$ & $\begin{array}{l}\text { Very general recommendations to increase } \\
\text { research and management }\end{array}$ & $\begin{array}{l}\text { Timberlake } \\
\text { (1998) }\end{array}$ \\
\hline $\begin{array}{l}\text { '...the fish stocks of this area, and the communities they support may } \\
\text { be at risk due to overexploitation and destructive fishing practices. } \\
\text { There is uncertainty regarding the actual state of fish stocks, due to the } \\
\text { complexity of the system and the limited biological surveys carried out } \\
\text { in this region...' (p. 111) } \\
\text { 'The most pertinent management issues can be identified as the } \\
\text { following: Commercialisation of the fisheries, especially large scale } \\
\text { operations; destructive fishing methods, such as drag netting and small } \\
\text { mesh sizes...' (p. 145) }\end{array}$ & $\begin{array}{l}\text { 'The complicated nature of the river/floodplain } \\
\text { habitats and the communities which use them, as } \\
\text { well as the linkages between different resource } \\
\text { uses means that it would be almost impossible } \\
\text { to separate fisheries management from other } \\
\text { resource use activities.' (p. 147) }\end{array}$ & $\begin{array}{l}\text { Abbott } \\
(2001)\end{array}$ \\
\hline $\begin{array}{l}\text { 'Fish sizes are perceived to have decreased in recent years and a greater } \\
\text { proportion of the fish are now species with high fecundity and a short } \\
\text { life span. These changes are typical of the impacts of the change } \\
\text { from large mesh }(150 \mathrm{~mm} \text { ) to those of a mesh size of } 35 \mathrm{~mm} \text { or less } \\
\text { (mosquito nets or even shade cloth).' (p. } 61 \text {; quoting from Bethune, } \\
\text { 1995) }\end{array}$ & $\begin{array}{l}\text { General need for increased regulation, but in } \\
\text { particular, increased awareness of the difference } \\
\text { in fishing methods by gender 'since women, who } \\
\text { often fish in shallow waters where fish breed, } \\
\text { may not be aware of conservation and wise use' } \\
\text { (p. 255) (emphasis added) }\end{array}$ & $\begin{array}{l}\text { Chenje } \\
(2000)\end{array}$ \\
\hline $\begin{array}{l}\text { '...clear evidence of overfishing in parts of the system, stemming from } \\
\text { a combination of ecological changes and increased fishing pressure due } \\
\text { to changes towards modern gear and disintegration of traditional fishery } \\
\text { management practices.' (p. 115) } \\
\text { 'Unfortunately, women are now subsidising traditional gear with modern } \\
\text { gear. For example, women are the main users of mosquito nets...' }\end{array}$ & $\begin{array}{l}\text { Management and protection of floodplain } \\
\text { fisheries, involvement of women and children in } \\
\text { conservation measures }\end{array}$ & $\begin{array}{l}\text { Okeyo } \\
(2000)\end{array}$ \\
\hline $\begin{array}{l}\text { 'The major cause for declining freshwater fish populations in Namibia } \\
\text { is overfishing.' (p. 136) }\end{array}$ & $\begin{array}{l}\text { Avoid 'overfishing and the use of unsustainable } \\
\text { methods for catching fish (such as the use of } \\
\text { mosquito nets that remove immature fish as well } \\
\text { as adults from the population).' (p. 138) }\end{array}$ & $\begin{array}{l}\text { Government } \\
\text { of Namibia } \\
(2004)\end{array}$ \\
\hline
\end{tabular}

River. A lodge's reputation is largely based on the quality of fishing, specifically the amount and especially the size of specific species that guests hope to catch. A recent exchange in the Namibian press illustrates how the degradation narrative is reproduced among recreational fishers. A letter to the editor written by British anglers expressed concern that tourists were hardly able to catch fish anymore. The authors stated that fishing lodge owners in the area (a large number of whom are expatriates) agreed, but were hesitant to speak out individually as 'fingers will be pointed' (The Namibian 2005a). The letter highlights several concerns, including the use of drag nets and small mesh nets that have caused a steep drop in the number of fish caught. The letter also asserts that if current complaints to authorities go unheeded, the fish may disappear and 'if there are no fish, soon then there will be no birds'.
The letter's author also claimed that Zambians were responsible for 90 percent of these apparently destructive practices. This allegation prompted the Zambian High Commissioner to respond in the same newspaper two weeks later, saying that his government was 'equally concerned over the depletion of stocks in the Zambezi' and acknowledged that some fishers 'use unorthodox methods of fishing - factors that contribute to the depletion of fish stocks' (The Namibian 2005b). The High Commissioner then stated that the fisheries management was largely devolved to traditional authorities, who were best positioned to monitor and enforce regulations. His letter also mentioned current efforts to coordinate enforcement activities by the Namibian and Zambian governments. Two weeks later, a letter from an owner of a fishing lodge on the Zambezi was published, saying that the problem of destructive 
fishing by Zambians was symptomatic of a larger problem of porous and corrupt border controls in Zambia allowing criminals and smugglers to pass freely (The Namibian 2005c).

In addition to increased enforcement, anglers particularly advocate the banning of drag netting and the implementation of closed seasons during fish breeding events (The Namibian 2005a, c). One author's (Abbott) experience during 2002, provides some insight into not only what some lodge owners feel is an appropriate management intervention, but also how it should be implemented. The owners of one lodge stated that they nested a species of cichlid fish, valued by anglers, concentrated in backwater adjacent to them during the breeding season. The owners feared that the concentration of fish, especially during an important time in their life cycle, made them vulnerable to local fishers who targeted these nesting sites. In response to these fears, the lodge owners stated that, during the breeding season, they keep a round-the-clock watch on the nesting site (an earlier lodge owner claimed to have permission to do so from the Traditional Authority). Their rationale, the lodge owners explained, was not to control fishing everywhere, but to keep the main breeding stock from being wiped out.

\section{Views of Floodplain Inhabitants}

The majority of floodplain inhabitants consulted asserted that fish abundance had declined over time, although different groups gave different reasons for this apparent decline. In a series of village meetings held in each floodplain administrative ward, the participants of the meeting cited increased levels of fishing and use of destructive methods as reasons for this perceived decline. Zambians were frequently mentioned as being responsible for a rise in fishing activity and identified as the main culprits in the use of destructive methods (Purvis et al. 2003).

Traditional authorities responsible for each administrative ward stated at the same meetings that several fishing methods were prohibited, including drag nets and small mesh, due to their negative effect on fish stocks. However, traditional authorities and fishers also said these restrictions were difficult to enforce, and that fishers were compelled to use them to get sufficient catches. At each village meeting, the consensus view was that the government should work with the floodplain inhabitants. In particular, participants voiced support for giving traditional authorities in each administrative ward the authority to enforce prohibitions on certain fishing methods. There was less support, however, for a closed season or the outright exclusion of Zambian fishers.

One issue that emerged from our research is that there has been an apparent change in the importance of fish as part of the subsistence and income livelihood strategy of the region's inhabitants. Results from an intensive survey of Namibian floodplain households in 2002 indicated that reliance on fish had increased over the five-year period identified in the survey. Respondents cited declining agricultural production (due to poor floods, drought, and animal damage), as the most important cause for their increased reliance on fishing (J. Abbott unpublished data). Interviews with key informants in 2002 and 2005 also provided an insight into the perceived changes in fish stocks over a longer time frame. Older inhabitants stated that until the 1960s, traditional fishing gear was more common. Nets that were previously handmade with cord from discarded tires were replaced by manufactured nets, which had originally been distributed by a fisheries development project in Zambia.

While none of the interviewees explicitly linked flooding and fish abundance, one elderly respondent mentioned changes in area hydrology and fauna:

'During that time [onset of the little rainy season, NovemberDecember] there were a lot of trees bearing fruit, which we ate. The trees are still there, but there is no more fruit. Maybe the roots can't reach water anymore. Even by this village you could see antelope coming right to the mulapo and we would sometimes hunt them. Elephant would also pass through, although only the Baswara knew how to hunt them. Now the elephants pass through on their way to the [Zambezi] river but there are no antelope'

Namibian village, December 2003

We draw attention to this account because it is reasonable to assume that wild fruit gathering and protein from game play an important part in subsistence diets, when available. As a result, changes in their availability would have an effect on the amount of time and relative returns of other livelihood strategies, such as fishing. If food, especially small game, became less abundant, fishing would become a more important source of protein. What is also evident is that for floodplain residents practicing diverse livelihoods, fisheries are one part of an overall strategy; what is happening in fisheries cannot be separated from this larger livelihood context (Purvis 2002a).

The reputation of Zambians being the most numerous and damaging fishers, as described earlier, must be placed into the context of the views collected during the 2002 frame survey, of the Zambians themselves. The first quote, from a middle-aged woman, echoes a common sentiment throughout the floodplain that fishers simply have no choice but to use intensive methods:

'How can we be told to use large mesh nets when we can only catch fish in small mesh? Even now the prisons in Sesheke and Mwandi are full of young men who have no choice but to become cattle rustlers.'

Zambian village, November 2002

A second quote, from an older man, suggests that spatial heterogeneity of fisheries abundance plays as important a role in fisher behaviour as seasonal cycles. At the same time, the statement reveals a tension between users who are ethnically contiguous and frequently related, yet are separated by an invisible national boundary:

'We [Zambians] feel bad when Namibians chase us away from their side of the river. We go to that side to fish because the fishing is better there. It is better because the land is lower 
on the Namibian side so there are more streams and swamps. On this side we have mostly cliffs'.

Zambian village, May 2002

Fish vendors at the region's only formal market also reflected the predominant perception of a change in the abundance of fish and its importance to the economy (Abbott et al. 2007b). In open-ended interviews, fish vendors stated that the number of people selling fish, as well as vendors overall, had increased over time. Respondents cited a series of dry years since 2000 as having caused an increase in fish vendors, as vegetable vendors switched to fishing and harder conditions overall created increased demand for off-farm income. Vendors were not sure if the overall catch had declined over time, but did say that fish bought at the riverside cost more and there was less to go around.

These results support the views asserted as part of an overfishing narrative that numbers of fishers and fishing settlements have increased over time, as has the reliance on fishing. Some fishers echoed the perception shared by other groups that the fishing intensity had increased and mesh sizes had declined, accompanied by a decline in fish catches. There is also support for the claim that 'outsiders' are encroaching on fishing grounds and traditional management has eroded. Similarly, fishers supported the banning of certain methods and the strengthening of traditional management measures.

\section{CONCLUSION: OVERFISHING NARRATIVES AND EMERGING MANAGEMENT}

In this final section of the article, we: (a) Review stakeholder positions and incentives for them, and how these positions reflect broader themes found in research on fisheries and their management; (b) Consider how some would-be indicators of overfishing might be interpreted differently in the local context; and (c) Reflect on what our analysis implies of our understanding of the narratives concept.

\section{Understanding Stakeholder Positions}

Ideas about the causes and effects of overfishing presented by researchers, policy makers, recreational fishers and floodplain inhabitants overlap, in that they all assume that changes to a fishery can occur under certain conditions. However, there are differences over the relative importance of natural and human factors in driving changes in a fishery, with researchers emphasizing the former, and policymakers, recreational fishers and local inhabitants' views emphasizing the latter.

Interpretations of change by researchers working in the area emphasize the role of intra-annual flooding trends affecting the productivity of fisheries, reflecting broader views of floodplain dynamics and non-equilibrial ecological systems. They also draw attention to how fishing methods are affected by seasonal variations in the habitat and damage by animals. In these ways, researchers largely resist conventional overfishing narratives, and they argue for more research in the region. Cochrane (2000; p. 12-13) asserts that highlighting uncertainty in fisheries management can be used as a tool for guarding against blame, establishing personal legitimacy or accessing funding. While this may or may not be the case for our researchers, they have consistently, over time, argued for caution in assuming cause and effect linkages in this highly variable environment.

These findings make our case stand in contrast to many others in Africa, where scientists have been implicated in uncritical formation, adoption and circulation of degradation narratives (Leach \& Mearns 1996; Keeley \& Scoones 2000). Moreover, discourse around the region's fishery did not emerge out of a seminal study, in contrast to the Ethiopian degradation narrative described by Keeley \& Scoones (2000). Ours is not a case of 'science versus users', where the views of resource users are disregarded or ignored in favour of scientific assertions about problems and the necessary solutions. Rather, locally based scientists can be depicted as challenging a narrative supported and promoted by some of their scientific peers. Similarly, in her work on marine protected areas in Belize, Gray (in review) found scientific disagreement between locally based scientists working for an NGO and visiting researchers. These findings reinforce Forsythe's (2003) critique of a tendency of those interested in narratives to assume oversimplified relationships between science and the policy process. They also highlight the importance of power in determining which narratives are adopted, and whose voices are heard in reinforcing or disputing them. However, while there has been much attention to the issue of diversity and power differentials among resource users (Agrawal \& Gibson 1999), there has been less attention to diversity among scientists (but see Campbell 2002). The relationships among scientists, science and policy-making are probably much more nuanced and multifarious than they are often portrayed.

Policy makers similarly acknowledge the effects of poor flooding. However, they largely adopt the overfishing narrative, stressing impacts from growth in the region's population, the nature of subsistence fishing activity and a decline in traditional management. Above all, policy makers are unequivocal about the current threats to the fishery caused by increased levels and intensity of fishing in the area. Policy-makers also emphasize a management vacuum in the region, related to declining traditional authority that results in the inability to address a present crisis. This vacuum justifies increased administrative involvement by the government and NGOs in an area that is attracting growing international attention, due to its tourism potential and transboundary nature (Abbott et al. 2007a).

Recreational fishers and lodge owners identified a decline in the species of fish targeted by visitors, as symptomatic of destructive subsistence fishing methods. They simultaneously assert the importance of recreational fishing to the area's economy and demonstrate how catch-and-release methods associated with angling contrast with the subsistence methods (Malasha 2003 \& McGregor 2005 for further examples of how conservation and aesthetics dichotomize fishing methods). In doing so, recreational fishers and lodge owners are better able to justify restrictions on fishing intensity and methods available to local fishers under the new Namibian legislation. 
It is not a problem of fishing per se, but the type and value of particular practices.

Floodplain inhabitants also identify declining catches and link the causes to the use of certain fishing methods and increased fishing pressure. The local version of the degradation narrative identifies both a threat and the cause, but in doing so identifies an 'outside' group, specifically Zambians, as 'culprits'. In identifying an outside culprit, attention to the role of fishing by women and children is somewhat reduced; the conflict between Namibian and Zambian fishers is usually construed as a conflict between men fishing with nets from boats, rather than women fishing from the shore. At the same time, the local narrative makes a clear argument for the role of inhabitants, in particular traditional authorities, in managing the fisheries. As fishing on the Zambian side of the river has increased, incentives for Namibian fishers to opt for more formal management have increased, as this potential allows them to address problems of exclusion. Given the ambiguous nature of the current policy towards institutional capacity and responsibility for fisheries management, it is understandable that the overfishing narrative constructed by local inhabitants legitimises the inclusion of certain local voices and institutions, especially traditional authorities.

The resonance of the overfishing narrative with diverse stakeholders surprised us, especially given the lack of supporting evidence in the local fisheries research. We were particularly surprised at the extent to which floodplain inhabitants adopted key elements of the narrative. On first glance, seemingly disparate and potentially at odds actors (such as fishing lodge owners and floodplain inhabitants) supported a shared narrative of a fisheries crisis. However, when we attended to the detail of the narrative, differences arose. In the case of fishing lodge owners and floodplain inhabitants, they might agree on the problem of overfishing, but they identified different culprits. In doing so, they were legitimising their own rights to use and manage a resource in a changing institutional environment. Thus, the potential for conflict here lay not in the adoption of the narrative itself, but in the subtle differences in emphasis and related implications for management intervention.

\section{Narratives in Context}

One of the strengths and weaknesses of narratives is their generality. As Roe (1991) has pointed out, narratives are supposed to reduce complexity in order to allow for decisionmaking. Attention to complexity can lead to paralysis, and simplifying a narrative helps to overcome this. The problems of simplification are many, and we have suggested here that the simplified linear model of fisheries overexploitation does not fit well with the complex biophysical and socio-economic context of this particular floodplain. Two important components of the narrative that overfishing results from increased fishers and intensive fishing methods can be interpreted very differently in the context of our study site. We consider three examples.

First, while the increase in the overall number of fishers, particularly from the Zambian side of the river (Abbott et al. 2007a), can be interpreted as supporting the overfishing narrative, this trend may not represent a unidirectional rush towards a last resort of the poor, but rather an elastic response to longer term shifts in the Zambian economy. As Gordon (2005) describes, the collapse of the price of copper led to a prolonged economic downturn in Zambia, causing many urban inhabitants to invest their labour and capital in fishing. Given Zambia's recent gains from record prices for the same commodity, it would be useful to determine if a reciprocal pull from the periphery to the core occurred and the numbers of fishers decreased.

Second, there have been considerable changes in the abundance and composition of wildlife in the area over the last 30 years, and this has impacted the fishing effort and practice. One well-recognised impact is the effect on agriculture through crop damage (O'Connell-Rodwell et al. 2000; Mulonga \& Murphy 2003), making farming more difficult. Less attention has been paid to how the decrease in small game (and prohibition on their use) removed this source of protein from most people interviewed for this study, likely affecting their perception of the importance of fishing and its relative ability to meet subsistence needs. Similarly, adoption of active fishing methods, such as drag netting with small mesh (something the overfishing narrative would accept as indicative of the problem), may be to avoid the risk of damage to nets by animals crossing rivers, particularly in areas within wildlife corridors (Robinson et al. 2001).

Finally, the use of mosquito nets by women is often a seasonal phenomenon, mediated as much by institutional dimensions of gender and class as by the efficiency of the method; fishing is in principle (rather than practice) a male activity. Our own research reflects the marginalised position of women in this sector; women are seldom recognised as fishers by governments, NGOs, traditional authorities, or by male fishers. Furthermore, women rarely identify themselves as fishers. Because we were often working with traditional authorities and/or government representatives in the field, and because it was clear that mosquito net fishing was a controversial and potentially illegal fishing method, we did not ask women directly about their own fishing activities unless they offered the information freely. Thus, our data collected from female fishers are limited, and most information came from fish vendors in the market who also caught some of their stock (gender divisions of labour run throughout the fishery, and in contrast to their marginal role in fishing, women dominate in fish vending (Abbott et al. 2007b). Further understanding of the importance of this activity and of its impacts on fish stocks is required before policy change is implemented, particularly as women themselves are unlikely to have much voice in this process.

Narratives serve a practical function because they are necessary to reduce complexity. However, they may be adopted and resonate for strategic reasons, or in a broader environmental and socioeconomic context that makes narrative uptake possible and desirable. For example, Keeley \& Scoones (2000) demonstrate how a series of good rains in the early 1990s opened up policy space for promoting aggressive 


\section{6 / Abbott and Campbell}

agricultural interventions in Ethiopia. The relative success of different approaches to agricultural extension in Ethiopia also depended on the ability of discourse to adapt to changing domestic and international politics. In our case study, the emergence of overfishing concerns coincided with a series of low floods and poor rainy seasons, combined with the growing cost of staples. At the same time, the region itself 'opened up', in the context of both geographical and policy space, with Namibia's independence. Research and policy intervention, especially by NGOs, expanded considerably as the region emerged from its previous status as a frontline for a bush war and part of a pariah state. This made specific policy-driven discourses, particularly those that resonate with international concerns, more likely to emerge and become established.

\section{Acknowledgements}

The authors are grateful to the inhabitants of the Upper Zambezi River for their cooperation. This research was made possible by funding from the Social Sciences and Humanities Research Council of Canada, the International Development Research Centre and the World Wide Fund for Nature. We also thank the reviewers for their useful comments on previous versions of this manuscript.

\section{Notes}

1. This reflects recent views in the media regarding the distribution of subsidized mosquito nets in Africa and their use for other purposes, including fishing. Examples include: 'Liberals, Conservatives and Aid' (Brooks 2005) and 'Net Gains for Africa' (Anonymous 2005) appearing in the New York Times and Los Angeles Times, respectively. The Wikipedia entry for 'malaria' goes so far as to take a single reference regarding mosquito nets in Namibia and generalize it the entire African continent. An online debate titled 'Mosquito nets and indiscriminate fishing, good or detrimental for Africa?' can also be found at Safaritalk, (http://safaritalk. net $/$ index.php?showtopic $=1532 \& s t=0$ ). An even more recent example can be found in Harper's Magazine (2009, p.84).

\section{REFERENCES}

Abbott, J.G. 2001. Traditional fisheries management in the Eastern Caprivi region of Namibia. In: FAO expert consultation on the management of small-scale fisheries in Sub-Saharan Africa. (ed. Scholtz U.) Pp. 109152. Ghana: COFAD.

Abbott, J.G. 2005. Fishing for a living: Subsistence and income uses of a common property resource in the upper Zambezi floodplains. Ph.D. thesis. Raleigh, North Carolina: Duke University. USA.

Abbott, J.G., L.M. Campbell, C. Hay, A. Ndumba, T. Næsje and J. Purvis. 2007a. Rivers as resources, rivers as borders: Community vs. transboundary management of fisheries in the upper Zambezi river floodplains. The Canadian Geographer 51(3): 280-302.

Abbott, J.G., L.M. Campbell, C. Hay, T. Næsje and J. Purvis. 2007b. Marketresource links and fish vendor livelihoods in the upper Zambezi river floodplains. Human Ecology 35(5): 559-574.

Abernethy, K., E. Allison, P. Molloy and I. Côté. 2007. Why do fishers fish where they fish? Using the ideal free distribution to understand the behaviour of artisanal reef fishers. Can J Fish Aquat Sci 64: 1595-1604.

Adams, W. 1993. Wasting the rain: Rivers, people and planning in Africa. Minneapolis: University of Minnesota Press.

Adger, N. and C. Luttrell. 2000. The values of wetlands: Landscape and institutional perspectives. Ecological Economics 35: 75-89.
Agrawal, A. and C. Gibson. 1999. Enchantment and disenchantment: The role of community in natural resource conservation. World Development 27(4): 629-649.

Akpalu, W. 2008. Fishing regulations, individual discount rate, and fisherman behaviour in a developing country fishery. Environment and Development Economics 13: 591-606.

Allan, J., R. Abell, Z. Hogan, C. Revenga, B. Taylor, R. Welcomme, and K. Winemiller. 2005. Overfishing of inland waters. Bioscience 55: 1041-1051.

Allison, E. and F. Ellis. 2001. The livelihoods approach and management of small-scale fisheries. Marine Policy 25(5): 377-388.

Alverson, D. 2002. Factors influencing the scope and quality of science and management decisions (The good, the bad and the ugly). Fish and Fisheries 3: 3-19.

Andrew, N., C. Béné, S. Hall, E. Allison, S. Heck and B. Ratner. 2007. Diagnosis and management of small-scale fisheries in developing countries. Fish and Fisheries 8: 227-240.

Anonymous. 2005. Net gains for Africa. Los Angeles: Los Angeles Times.

Arthington, A., K. Lorenzen, B. Pusey, R Abell, A. Halls, K. Winemiller, D. Arrington, et al. 2003. River fisheries: Ecological basis for management and conservation. In: Ecology and Management of Large Rivers. (eds. Welcomme R. and T. Petr). Cambodia: Mekong River Commission, Phonm Penh.

Ashley, C. and C. LaFranchi. 1997. Livelihood strategies of rural households in Caprivi: Implications for conservancies and natural resource management. Namibia: Directorate of Environmental Affairs, Ministry of Environment and Tourism.

Barnard, P. (ed.). 1998. Biological diversity in Namibia: A country study. Namibia: Namibian National Biodiversity Task Force.

Bassett, T. and D. Crummey. (eds.). 2003. African savannas: Global narratives and local knowledge of environmental change. Oxford: James Currey.

Basurto, X. 2008. Biological and ecological mechanisms supporting marine self-governance: The Seri Callo de Hacha fishery in Mexico. Ecology and Society 13(2): 20.

Beddington, J., D. Agnew and K. Clark. 2007. Current problems in the management of marine fisheries. Science 316: 1713-1716.

Bell-Cross, G. 1974. A fisheries survey of the upper Zambezi river system. Occasional Articles of the National Museums and Monuments of Rhodesia 5(5): 278-338.

Béné, C. 2005. Contribution of inland fisheries to rural livelihoods and food security in Africa: An overview. In: Freshwater ecoregions of Africa and madgascar: A conservation assessment. (eds. Thieme, M., R. Abell, M. Stiassnyand and P. Skelton). Pp. 6-11.Washington, DC: Island Press.

Brooks, D. 2005. Liberals, conservatives and aid. New York: The New York Times.

Byers, B. 1997. Environmental threats and opportunities in Namibia: A comprehensive assessment. department of environmental affairs. Namibia: Ministry of Environment and Tourism.

Campbell, L.M. 2000. Human need in rural developing areas: Perceptions of wildlife conservation experts. The Canadian Geographer 44(2): 167-181.

Campbell, L.M. 2002. Science and sustainable use: Views of conservation experts. Ecological Applications 12(4): 1229-1246.

Campbell, L.M. 2007. Reconciling local conservation practice with global discourse: A political ecology of sea turtle conservation. Annals of the Association of American Geographers 97(2): 313-334.

Campbell, L.M., N.J. Gray, E.L. Hazen and J.M. Shackeroff. 2009. Beyond baselines: Rethinking priorities for ocean conservation. Ecology and Society 14(1): 14.

Chenje, M. (ed.). 2000. State of the environment Zambezi basin 2000. SADC/ IUCN/ZRA/SARDC. Zambia: Lusaka.

Cinner, J., T. Daw and T. McClanahan. 2008. Socioeconomic factors that affect artisanal fishers' readiness to exit a declining fishery. Conservation 
Biology 23: 124-130.

Coates, D., W. Boivin, R. Friend, A. Hirsch, A. Poulsen, R. Quiros, T. Visser, et al. 2003. Session 5 review: Information, knowledge and policy. In: Ecology and management of large rivers. (eds. Welcomme R. and T. Petr). Cambodia: Mekong River Commission.

Cochrane, K. 2000. Reconciling sustainability, economic efficiency and equity in fisheries: The one that got away? Fish and Fisheries 1: 3-21.

Crowder, L., E. Hazen, N. Avissar, R. Bjorkland and C. Latanich. 2008. The impacts of fisheries on marine ecosystems and the transition to ecosystem-based management. Annu Rev Ecol Evol Syst 39: 259-78.

De Graaf, G. 2003. The flood pulse and growth of floodplain fish in Bangladesh. Fisheries Management and Ecology 10: 241-247.

Evans, M. and Y. Mohieldeen. 2002. Environmental change and livelihood strategies: The case of lake chad. Geography 87(1): 3-13.

Evans-Pritchard, E. 1940. The Nuer. London: Oxford University Press.

FAO. 1996. Fisheries and aquaculture in Sub-Saharan Africa: Situation and outlook in 1996. FAO fisheries circular \# 922. Food and agricultural organization. Rome: United Nations.

FAO. 2003. Review of the state of world fishery resources: Inland fisheries. FAO fisheries circular \# 942. Food and agricultural organization. Rome: United Nations.

FEWS (Famine early warning system network). 2002. Food security prospects worrisome http: //www.fews.net/centers/innerSections. aspx? $\mathrm{f}=\mathrm{r} 3 \mathrm{andm} 1000783=$ andpageID $=$ monthliesDoc. Accessed March 222006.

Fisch, M. 1999. The Caprivi strip during the German colonial period 1980 to 1914. Namibia: Out of Africa Publishers.

Forsyth, T. 2003. Critical political ecology. London: Routledge.

Fox, C. and C. Sneddon. 2005. Flood pulses, international watercourse law and common pool resources. World institute for development economics research, Stockholm: Expert Group on Development Issues.

Gillson, L., M. Sheridan and D. Brockington. 2003. Representing environments in flux: Case studies from east Africa. Area 35(4): 371-389.

Gordon, D. 2005. Growth without capital: A renascent fishery in Zambia and Katanga, 1960s to recent times. Journal of Southern African Studies 31(3): 495-511.

Government of Namibia. 1996. White paper on the responsible management of the inland fisheries of Namibia. Windhoek: Government Printers.

Government of Namibia. 2003. Inland fisheries act. Windhoek: Government Printers.

Haller, T. and S. Merten. 2008. "We are Zambians-Don't tell us how to fish!" Institutional change, power relations and conflicts in the Kafue flats fisheries in Zambia. Human Ecology 36: 699-715.

Hardin, G. 1968. The tragedy of the commons. Science 162: 1243-1248.

Harper's Magazine. 2009. 'Findings'. February. p. 84.

Hay, C., T. Næsje, S. Kapirika, J. Koekemor, R. Strand, E. Thorstad and K. Harsaker. 2002. Fish populations, gill net catches and gill net selectivity in the Zambezi and Chobe Rivers, Namibia, from 1997 to 2000. NINA-NIKU Project Report \#17. NINA-NIKU Foundation for Nature Research, Tromso, Norway.

Hay, C., T. Næsje, O. Sandlund, E. Thorstad, J. Kolding and B. Zyl. 2002. Exploitation and management of fish resources in the Okavango River, Namibia. Environmental monitoring of tropical and subtropical wetlands workshop, Maun, Botswana.

Herbert, E. 2002. Twilight on the Zambezi: Late colonialism in central Africa. New York: Palgrave Macmillan.

Hickling, C. 1961. Tropical inland fisheries. New York: Wiley.

Hilborn, R., J. Orensanz and A. Parma, 2005. Institutions, incentives and the future of fisheries. Philosophical Transactions of the Royal Society B-Biological Sciences 360: 47-57.

Hinz, M. 2003. Without chiefs there would be no game: Customary law and nature conservation. Windhoek: Out of Africa Publishers.
Hoggarth, D., V. Cowan, A. Halls, M. Aeron-Thomas, J. McGregor, C. Garaway, I. Payne, et al. 1999. Management guidelines for Asian floodplain river fisheries. FAO Fisheries Technical Paper 384/2. Food and agricultural organization. Rome: United Nations.

Hulme, D. and M. Murphree (eds.). 2001. African wildlife and livelihoods: The promise and performance of community conservation. Oxford: James Currey.

Jackson, P. 2000. Freshwater fishery research organisations in central and eastern Africa: A personal recollection. Transactions of the Royal Society of South Africa 55: 1-75.

Johnson, D. and D.M. Anderson. (eds.). 1988. The ecology of survival, Boulder: Westview Press.

Jul-Larsen, E., J. Kolding, R. Overa, J. Nielsen and P. Zwieten. 2003. Management, co-management or no management? Major dilemmas in Southern Africa freshwater fisheries. FAO fisheries technical paper 426/1. Food and agricultural organization. Rome: United Nations.

Junk, W., P. Bayley and R. Sparks. 1989. The flood pulse concept in riverfloodplain systems. Canadian Special Publications of Fisheries and Aquatic Sciences 106: 110-127.

Keeley, J. and I. Scoones. 2000. Knowledge, power and politics: The environmental policy-making process in Ethiopia. The Journal of Modern African Studies 38: 89-120.

Koekemor, J. 2003. A fish ecological study of rivers and flooplains of the Eastern Caprivi, Namibia. M.Sc. Thesis, Rand Afrikaans University, Pretoria, South Africa.

Laë, R. 1997. Does overfishing lead to a decrease in catches and yields? An example of two West African coastal lagoons. Fisheries Management and Ecology 4: 149-164.

Leach, M. and R. Mearns. 1996. Challenging received wisdom in Africa. In: The lie of the land: Challenging received wisdom on the African environment. (eds. Leach M. and R. Mearns). Pp. 1-33. Oxford: James Currey.

Lindholm, M., D. Hessen, K. Mosepele and P. Wolski. 2007. Food webs and energy fluxes on a seasonal floodplain: The influence of flood size. Wetlands 4: 775-784.

Malasha, I. 2003. Colonial and postcolonial fisheries regulations: The cases of Zambia and Zimbabwe. In: Management, co-management or no management? Major dilemmas in southern African freshwater fisheries. (eds. Jul-Larsen, E., J. Kolding, R. Overaa, J. Nielsen and P. van Zweiten). Rome: Food and Agricultural Organization.

Mazvimavi, M. and P. Wolski. 2006. Long-term variations of annual flows of the Okavango and Zambezi rivers. Physics and Chemistry of the Earth 31: 944-951.

McClanahan, T., D. Hicks and E. Darling. Malthusian overfishing and efforts to overcome it on Kenyan reefs. Ecological Applications 18: 1516-1529.

McGoodwin, J. 2001. Understanding the cultures of fishing communities: A key to fisheries management and food security. FAO fisheries technical paper 401. Food and Agricultural Organization. Rome: United Nations.

McGregor, J. 2005. Crocodile crimes: People versus wildlife and the politics of postcolonial conservation on Lake Kariba, Zimbabwe. Geoforum 36: 353-369.

Mendelsohn, J. and C. Roberts. 1997. An environmental profile and atlas of the Caprivi. Windhoek: Gamsberg Macmillan.

Millennium ecosystem assessment. 2005. Ecosystems and human well-being: Biodiversity synthesis. Washington, DC: World Resources Institute.

Mosepele, K., T. Mmopelwa and B. Mosopele. 2002. Characterization and monitoring of the Okavango delta artisanal fishery. Environmental monitoring of tropical and subtropical wetlands workshop. Botswana: University of Botswana.

Mosugelo, D., S. Moe, S. Ringrose and C. Nelleman. 2002. Vegetation changes during a 36-year period in northern Chobe National Park, Botswana. African Journal of Ecology 40: 232-240.

Mugisha, A. 2003. Fisheries in national parks: A case study of lake Mburo national park, Uganda. In: Conservation, ecology and management of African fresh waters. (eds. Crisman, T., L. Chapman, C. Chapman 


\section{8 / Abbott and Campbell}

and L. Kaufman). Pp. 430-443. Gainesville: Florida University Press.

Mullon, C., P. Fréon and P. Cury. 2005. The dynamics of collapse in world fisheries. Fish and Fisheries. 6: 111-120.

Mulonga, S., C. Murphy and H. Suich. 2003. The conflict continues: Human wildlife conflict and livelihoods in Caprivi. Research discussion paper. Namibia: Ministry of Environment and Tourism,.

Muncy, R. 1978. An evaluation of the Zambian Kafue river floodplain fishery. Food and agricultural organization. Rome: United Nations.

Murphy, C. and J. Abbott. 2006. A description and preliminary assessment of participatory development policies and application in Namibia. Tanzania Journal of Development Studies. 6(1): 47-56.

Næsje, T., C. Hay, S. Kapirika, O. Sandlund and E. Thorstad. 2001. Some ecological and socio-economic impacts of an angling competition in the Zambezi River, Namibia. NINA-NIKU project report \#14. Tromso: NINA-NIKU Foundation for Nature Research.

Næsje, T., R. Strand, C. Hay, J. Purvis, E. Thorstad, J. Abbott and N. Nickanor. 2002. Shared resource management on the Zambezi/Chobe systems in northeast Namibia: Current practices and future opportunities river survey February-August 2002. Namibia: Unpublished Report to LIFEWWF.

Namibia Tourism Board. 2009. Tourist accommodation statistics preliminary: Table annexure Jan-Aug 08. http: //www.namibiatourism.com.na/ trade_docs/tables_report_janaug08.pdf. Accessed on March 19, 2009.

Naeraa, T., S. Devereu, B. Frayne and P. Harnettt. 1993. Coping with drought in Namibia: Informal security systems in Caprivi and Erongo. Namibia: Namibian Institute for Social and Economic Research.

Nakayama, M. (ed.). 2003. International waters in southern Africa. Tokyo: United Nations University Press.

New Era. 2008. 'Kamwi warns on abuse of mosquito nets' (no date).

O'Connell-Rodwell, C., T. Rodwell, M. Rice and L. Hart. 2000. Living with the modern conservation paradigm: Can agricultural communities coexist with elephants? A five-year case study in East Caprivi, Namibia. Biological Conservation 93: 381-391.

Okeyo, D. 2000. Inland fisheries development in Namibia: Evaluating alternative paths for sustainable development. In: Populationdevelopment-environment in Namibia: Background readings. (eds. Fuller B. and I. Prommer). Pp. 109-134. Laxenburg: International Institute for Applied Systems Analysis.

Panyotou, T. 1982. Management concepts for small-scale fisheries: Economic and social aspects. FAO fisheries technical paper 228. Food and Agricultural Organization. Rome: United Nations.

Parma, A., R. Hilborn and J. Orensanz. 2006. The good, the bad, and the ugly: Learning from experience to achieve sustainable fisheries. Bulletin of Marine Science 78(3): 411-428.

Pauly, D., G. Silvestre and I. Smith. 1989. On development, fisheries, and dynamite: A brief review of tropical fisheries management. Natural Resource Modelling 16: 121-127.

Pauly, D. 1997. Small-scale fisheries in the tropics: Marginality, marginalization and some implications for fisheries management. In: Global trends: Fisheries management. (eds. Huppert D. and M. Sissenwine). Pp. 40-49. Bethesda: American Fisheries Society.

Pauly, D., R. Watson and J. Alder. 2005. Global trends in world fisheries: Impacts on marine ecosystems and food security. Philosophical Transactions of the Royal Society B-Biological Sciences 360: 5-12.

Poff, N., M. Allan, M. Bain, K. Karr, B. Prestegaard, R. Richter, R. Sparks. et al. 1997. The natural flow regime: A paradigm for river conservation and restoration. Bioscience 47: 769-784.

Purvis, J. 2002a. Fish and livelihoods: Fisheries on the eastern floodplains, Caprivi. Directorate of Environmental Affairs. Namibia: Ministry of Environment and Tourism.

Purvis, J. 2002b. Postharvest fisheries on the eastern floodplains, Caprivi. Directorate of Environmental Affairs. Namibia: Ministry of Environment and Tourism.

Purvis, J., J. Abbott, T. Næsje and C. Hay. 2003. Shared resource management on the Zambezi/Chobe systems in northeast Namibia: Current practices and future opportunities; Existing fishery management systems and implications for future management. Namibia: Unpublished Report to LIFE-WWF.

Robbins, P. 2004. Political ecology: A critical introduction. Ames: Blackwell Publishing.

Robinson, J., K. Lulla, M. Kashiwagi, M. Suzuki, D. Nellis, C. Bussing, W. Long, et al. 2001. Conservation applications of astronaut photographs of earth: Tidal-flat loss (Japan), Elephant effects on vegetation (Botswana), and Seagrass and mangrove monitoring (Australia). Conservation Biology 15: 876-884.

Roe, E. 1991. Development narratives or making the best of blueprint development. World Development 23: 287-300.

Sadoff, C., D. Whittington and D. Grey. 2002. Africa's international rivers: An economic perspective. Washington: The World Bank.

Salas, D and D. Gaertner. 2004. The behavioural dynamics of fishers: Management implications. Fish and Fisheries 5: 153-167.

Sadovy, Y. 2005. Trouble on the reef: The imperative for managing vulnerable and valuable fisheries. Fish and Fisheries 6: 167-185.

Sarch, M.T. 1996. Fishing and farming at lake Chad: Overcapitalization, opportunities and fisheries management. Journal of Environmental Management 48: 305-320.

Sarch and Birkett, C. 2000. Fishing and farming at lake Chad: Responses to lake-level fluctuations. The Geographical Journal 166(2): 156-172.

Schlettwein, C., R. Simmons, A. MacDonald, and H. Grobler. 1991. Flora, fauna and conservation of East Caprivi wetlands. MADOQUA 17: 67-76.

Scudder, T and T. Connelly. 1985. Management systems for riverine fisheries. Rome: Food and Agriculture Organization.

Shorr, N. 2000. Early utilization of flood recession soils as a response to the intensification of fishing and upland agriculture: Resource-use dynamics in a large Tikuna community. Human Ecology 28(1): 73-107.

Smith, T and J. Link. 2005. Autopsy your dead and living: A proposal for fisheries science, fisheries management and fisheries. Fish and Fisheries 6: 73-87.

The Namibian. 2004. Almost 1000 flood-affected villagers evacuated in Caprivi. Namibia: The Namibian.

The Namibian. 2005a. Concerns about the Zambezi. Namibia: The Namibian.

The Namibian. 2005b. Zambia on Zambezi complaints. Namibia: The Namibian.

The Namibian. 2005c. Not playing the game. Namibia: The Namibian.

Thomas, D.H.L. 1995. Artisanal fishing and environmental change in a Nigerian floodplain wetland. Environmental Conservation 22(2): 117-126.

Thomas and Adams, W. 1997. Space, time and sustainability in the HadejiaJamaare wetlands and the Komodugu Yobe Basin, Nigeria. Transactions of the Institute of British Geographers 22: 430-449.

Thomas and M. Danjaji. 1997. Mapping change in time and space: Floodplain fishing communities in Nigeria. PLA Notes 30: 29-33.

Thomas and C. Twyman. 2005. Equity and justice in climate change adaptation amongst natural-resource-dependent societies. Global Environmental Change 15: 115-124.

Timberlake, J. 1998. Biodiversity of the Zambezi Basin Wetlands: Review and preliminary assessment of available information. Harare: IUCN-ROSA.

Turpie, J., B. Smith, L. Emerton and J. Barnes. 1999. Economic value of the Zambezi Basin wetlands. Cape Town: University of Cape Town.

Tvedten, I., S. Girvan, N. Pomuti and R. Van Roy. 1994. Freshwater fisheries and fisheries management in Namibia. Windhoek: Social Science Division. Namibia: University of Namibia.

Tvedten, I. 2002. If you don't fish, you are not a Caprivian: Freshwater fisheries in Caprivi, Namibia. Journal of Southern African Studies 28(2): 421-439.

Tweddle, D. 2004. Surveys of the Upper Zambezi River system. Ichthos 5: 7-10.

Van der Waal, B. and P. Skelton. 1984. Check list of fishes of the Caprivi. Madoqua 13(4): 303-320.

Van der Waal, B. 1990. Aspects of the fishery of the eastern Caprivi. Madoqua 
17(1): $1-16$.

Van Langenhove, G., M. Amakali and B. de Bruine. 1998. Variability of flow regimes in Namibian rivers: Natural and human induced causes. Paper presented at a Conference on Water Resources Variability in Africa during the $\mathrm{XX}^{\text {th }}$ Century. Abidjan, Cote d'Ivoire.

Welcomme, R. 1979. The fisheries ecology of floodplain rivers. London: Longman.

Welcomme, R. 1999. A review of a model for qualitative evaluation of exploitation levels in multi-species fisheries. Fisheries Management and Ecology 6: 1-19.

Winemiller, K. 2004. Floodplain river food webs: Generalizations and implications for fisheries management. In: Ecology and management of large rivers. (eds. Welcomme, R. and T. Petr). Pp. 1-59. Phonm Penh: Mekong River Commission.

Winklerprins, A. 2003. Seasonal floodplain-upland migration along the lower Amazon River. Geographical Review 92: 415-431.

Worm, B., E.B. Barbier, N. Beaumont, J.E. Duffy, C. Folke, B.S. Halpern, J.B. Jackson, et al. 2006. Impacts of biodiversity loss on ocean ecosystem services. Science 314: 787-790.

Zeller, K. 1998. We used to be fishermen Changing rural livelihoods and decision making in East Caprivi, Namibia. M.Sc. Thesis. Helsinki, University of Helsinki, Finland.

\section{Staying in touch with the journal}

1) Table of Contents (TOC) email alert Receive an email alert containing the TOC when a new complete issue of the journal is made available online. To register for TOC alerts go to www.conservationandsociety.org/signup.asp.

\section{2) RSS feeds}

Really Simple Syndication (RSS) helps you to get alerts on new publication right on your desktop without going to the journal's website. You need a software (e.g. RSSReader, Feed Demon, FeedReader, My Yahoo!, NewsGator and NewzCrawler) to get advantage of this tool. RSS feeds can also be read through FireFox or Microsoft Outlook 2007. Once any of these small (and mostly free) software is installed, add www.conservationandsociety.org/rssfeed.asp as one of the feeds. 